\title{
GOME-2 total ozone columns from MetOp-A/MetOp-B and assimilation in the MACC system
}

\author{
N. Hao ${ }^{1}$, M. E. Koukouli ${ }^{2}$, A. Inness ${ }^{3}$, P. Valks ${ }^{1}$, D. G. Loyola ${ }^{1}$, W. Zimmer ${ }^{1}$, D. S. Balis ${ }^{2}$, I. Zyrichidou ${ }^{2}$, \\ M. Van Roozendael ${ }^{4}$, C. Lerot $^{4}$, and R. J. D. Spurr ${ }^{5}$ \\ ${ }^{1}$ Institut für Methodik der Fernerkundung (IMF), Deutsches Zentrum für Luft- und Raumfahrt (DLR), \\ Oberpfaffenhofen, Germany \\ ${ }^{2}$ Laboratory of Atmospheric Physics, Aristotle University of Thessaloniki, Thessaloniki, Greece \\ ${ }^{3}$ ECMWF, Reading, UK \\ ${ }^{4}$ Belgian Institute for Space Aeronomy, Brussels, Belgium \\ ${ }^{5}$ RT Solutions, Inc., Cambridge, Massachusetts, USA \\ Correspondence to: N. Hao (nan.hao@dlr.de)
}

Received: 20 December 2013 - Published in Atmos. Meas. Tech. Discuss.: 7 March 2014

Revised: 15 August 2014 - Accepted: 18 August 2014 - Published: 12 September 2014

\begin{abstract}
The two Global Ozone Monitoring Instrument (GOME-2) sensors operated in tandem are flying onboard EUMETSAT's (European Organisation for the Exploitation of Meteorological Satellites) MetOp-A and MetOp-B satellites, launched in October 2006 and September 2012 respectively. This paper presents the operational GOME-2/MetOp-A (GOME-2A) and GOME2/MetOp-B (GOME-2B) total ozone products provided by the EUMETSAT Satellite Application Facility on Ozone and Atmospheric Chemistry Monitoring (O3M-SAF). These products are generated using the latest version of the GOME Data Processor (GDP version 4.7). The enhancements in GDP 4.7, including the application of Brion-DaumontMalicet ozone absorption cross sections, are presented here. On a global scale, GOME-2B has the same high accuracy as the corresponding GOME-2A products. There is an excellent agreement between the ozone total columns from the two sensors, with GOME-2B values slightly lower with a mean difference of only $0.55 \pm 0.29 \%$. First global validation results for 6 months of GOME-2B total ozone using groundbased measurements show that on average the GOME-2B total ozone data obtained with GDP 4.7 are slightly higher than, both, Dobson observations by about $2.0 \pm 1.0 \%$ and Brewer observations by about $1.0 \pm 0.8 \%$. It is concluded that the total ozone columns (TOCs) provided by GOME$2 \mathrm{~A}$ and GOME-2B are consistent and may be used simultaneously without introducing systematic effects, which has
\end{abstract}

been illustrated for the Antarctic ozone hole on 18 October 2013. GOME-2A total ozone data have been used operationally in the Copernicus atmospheric service project MACC-II (Monitoring Atmospheric Composition and Climate - Interim Implementation) near-real-time (NRT) system since October 2013. The magnitude of the bias correction needed for assimilating GOME-2A ozone is reduced (to about $-6 \mathrm{DU}$ in the global mean) when the GOME-2 ozone retrieval algorithm changed to GDP 4.7.

\section{Introduction}

The Montreal Protocol and its amendments were designed to reduce the production and consumption of ozone depleting substances and should lead to a gradual recovery of earth's fragile ozone layer. However, the timing of full ozone recovery and the relation between the ozone layer and on-going climate change are still unclear.

The Global Ozone Monitoring Experiment 2 (GOME-2) instruments were launched onboard the EUMETSAT (European Organisation for the Exploitation of Meteorological Satellites) MetOp-A (October 2006) and MetOp-B (September 2012), respectively. MetOp-A and MetOp-B are flying on sun-synchronous orbits with a repeat cycle of 29 days and an Equator crossing time of 09:30 local time (descending mode). GOME-2 extends the long-term atmospheric 
composition measurements started by the ESA (European Space Agency) missions GOME/ERS-2 (European Remote Sensing Satellite; 1995) and continued with SCIAMACHY (SCanning Imaging Absorption spectroMeter for Atmospheric CHartographY)/ENVISAT (2002). GOME-2 is a nadir-scanning UV-VIS (ultraviolet-visible) spectrometer, covering the spectral range between 240 and $790 \mathrm{~nm}$ with a relatively high spectral resolution (Munro et al., 2006). The default swath width of the GOME-2 scan is $1920 \mathrm{~km}$, which enables global coverage in about 1.5 days. GOME-2 ground pixels have a default footprint size of $80 \times 40 \mathrm{~km}^{2}$ which is four times smaller than those for GOME $\left(320 \times 40 \mathrm{~km}^{2}\right)$ but larger than those for SCIAMACHY $\left(30 \times 60 \mathrm{~km}^{2}\right)$ and OMI (Ozone Monitoring Instrument; $24 \times 13 \mathrm{~km}^{2}$ at nadir). In the tandem mode, GOME-2/MetOp-A (hereafter GOME2A) operates on a reduced swath with of $960 \mathrm{~km}$ with an increased spatial resolution (approximately $40 \times 40 \mathrm{~km}^{2}$ ) while GOME-2/MetOp-B (hereafter GOME-2B) operates on a nominal wide swath at $1920 \mathrm{~km}$. This implementation increases both the daily coverage and the spatial resolution of GOME-2 measurements. GOME-2 tandem operations started on 15 July 2013.

The ozone total columns from GOME-2A have been processed operationally by the DLR (German Aerospace Center) using the GOME Data Processor (GDP) 4.4 algorithm as part of the EUMETSAT's Satellite Application Facility on Ozone and Atmospheric Chemistry Monitoring (O3MSAF) project (Loyola et al., 2011). Several algorithm improvements were introduced in the GDP 4.4 compared to previous versions (Van Roozendael et al., 2006), such as improved cloud retrieval algorithms, an intracloud ozone correction and an empirical correction to eliminate scan angle dependencies. Three years (2007-2009) of total ozone measurements from GOME-2A were validated using groundbased measurements (Loyola et al., 2011). The validation results show that in the tropics, GOME-2 data underestimate ground-based Dobson ozone by $0-2 \%$, while at middle latitudes the GOME- 2 total ozone overestimate in the Southern Hemisphere and underestimate ground-based measurements in the Northern Hemisphere by around $0.5 \%$. At the southern high latitudes, an underestimation of less than $1 \%$ is observed, while at the northern high latitudes, a good comparison relative to the Dobson measurement is found. Koukouli et al. (2012) assessed 5 years (2007-2011) of GOME-2A total ozone columns through an intercomparison with GOME/ERS-2, SCIAMACHY/ENVISAT, and $\mathrm{OMI} /$ Aura ozone data by a validation with ground-based measurements. These two studies show that the GOME-2 total ozone obtained with GDP 4.4 has good stability and high accuracy within the $\pm 1 \%$ level, making it suitable for inclusion in the satellite long-term, global total ozone record. However, GDP 4.4 data sets have a general tendency to underestimate total ozone in comparison to reference groundbased measurements and other satellite measurements.
The operational GOME-2 total ozone columns from MetOp-A and MetOp-B are generated at the DLR using the UPAS (Universal Processor for UV/VIS Atmospheric Spectrometers) environment version 1.3.9, implementing the level-1-to-2 GDP 4.7 algorithm. On 15 July 2013, the operational dissemination of the GOME-2B near-real-time (NRT) products including total ozone via EUMETCast started. GOME-2 level 2 near-real-time total column products from MetOp-A and MetOp-B are freely available in less than $2 \mathrm{~h}$ after sensing on an operational 24/7 basis. Details about the GOME-2 data transport and processing can be found in Valks et al. (2011).

An important application of the GOME-2 total ozone record is its deployment within the MACC-II (Monitoring Atmospheric Composition and Climate - Interim Implementation) project (www.gmes-atmosphere.eu). MACC-II (and the predecessor project MACC, both in the following referred to as MACC) is the (pre-)operational atmospheric core service of the European Copernicus/GMES (Global Monitoring for Environment and Security) programme funded by Seventh Framework Programme of the European Union (Hollingsworth et al., 2008). The service combines a stateof-the art transport and chemistry model with satellite data from various sensors to provide consistent analyses of 3dimensional fields of atmospheric composition including ozone. The MACC system is run routinely every day to provide NRT 5-day forecasts of atmospheric composition and was used to produce a 10-year reanalysis of atmospheric composition data (Inness et al., 2013). GOME-2A data have been assimilated in the MACC NRT analysis since 7 October 2013.

In the following, we discuss the consistency between the GOME-2 total ozone columns from MetOp-A and MetOp-B, including an initial validation with ground-based total ozone measurements. In Sect. 2 we describe the new GDP 4.7 algorithm used for the operational processing of GOME-2 total ozone columns. In Sect. 3 we analyse the consistency between GOME-2A and GOME-2B total ozone columns. In Sect. 4 we present the combined use of GOME-2A and GOME-2B total ozone data for the 2013 Antarctic ozone hole. The validation of GOME-2A and GOME-2B total ozone data and the use of GOME-2 total ozone columns in the MACC NRT system are discussed in Sects. 5 and 6 respectively. The paper ends with summary and conclusions.

\section{GDP 4.7 total ozone algorithm}

The operational GOME-2 total ozone products are generated using the GDP version 4.7, which is the latest version of GDP 4 algorithm (Van Roozendael et al., 2006; Loyola et al., 2011). Trace gas retrievals are performed using the Differential Optical Absorption Spectroscopy (DOAS) algorithm.

The first algorithm component is the DOAS fitting (Platt and Stutz, 2008). The slant column fitting is based on Beer's 
law for trace gas absorption, and includes a polynomial closure term to deal with broadband signatures over the 325 $335 \mathrm{~nm}$ fitting window. The fitting includes an effective temperature for the ozone absorption (see Sect. 2.1), an $\mathrm{NO}_{2}$ absorption cross section, wavelength registration for resampling the earthshine spectrum, and scaling factors for interference due to the Ring effect.

The next step is the computation of vertical column density (VCD) using an iterative air mass factor (AMF). The multiple scattering radiative transfer code LIDORT (Linearized Discrete Ordinate Radiative Transfer; Spurr, 2008) is used to calculate AMFs at $325.5 \mathrm{~nm}$. Computation of the VCD proceeds iteratively (the superscript $n$ indicates the iteration number) using the formula

$V^{(n+1)}=\frac{\frac{E}{M^{(n)}}+\Phi G^{(n)} A_{\text {cloud }}^{(n)}}{(1-\Phi) A_{\text {clear }}^{(n)}+\Phi A_{\text {cloud }}^{(n)}}$,

where $V$ is $\mathrm{VCD}, E$ is the DOAS-retrieved slant column, $\Phi$ is the intensity-weighted cloud fraction, and $M$ is the molecular Ring correction (Van Roozendael et al., 2006). $G$ is the ghost column, given by the formula

$G=V_{\mathrm{bc}}\left(1+c_{\mathrm{a}} \cos (\theta)-\cos (\theta)\right)$,

where $V_{\mathrm{bc}}$ is the climatological ozone column below cloud top, $c_{\mathrm{a}}$ the cloud albedo and $\theta$ the solar zenith angle (SZA). The $A_{\text {clear }}^{(n)}$ (the clear sky AMF) and $A_{\text {cloud }}^{(n)}$ (the AMF for the atmosphere down to the cloud-top level) and the ghost column $G^{(n)}$ (the quantity of ozone below the cloud top height) depend on the value of $V^{(n)}$ at the $n$th iteration step. In this formulation, $E$ reflects the true state of the atmosphere and acts as a constraint on the iteration. The iteration stops when the relative change in $V$ is less than a prescribed small number $(0.1 \%$ is used in GDP 4.7$)$. The cloud parameters are retrieved from GOME-2 measurements using the OCRA (Optical Cloud Recognition Algorithm) and ROCINN (Retrieval of Cloud Information using Neural Networks) algorithms (Loyola et al., 2007) and the ozone absorption inside and below the cloud is treated by the intracloud correction term, which is a function of the SZA and the cloud albedo (Loyola et al., 2011).

The algorithm improvements introduced in the GDP 4.7 are described in detail in Sects. 2.1 and 2.2.

\subsection{Selection of ozone absorption cross sections}

Ozone absorption cross sections are essential input reference data in the retrieval of total ozone and other trace gases from satellite and ground-based instruments (Lerot et al., 2009; Orphal, 2002, 2003). The uncertainty in the cross sections is an important source of retrieval error which can result in systematic biases of about $\pm 2 \%$ in the retrieved ozone columns (Van Roozendael et al., 2002; Weber et al., 2011). For total ozone retrieval from satellite instruments measuring in the
UV wavelength range, flight model (FM) cross sections measured with the instrument spectrometer prior to launch are commonly used. The use of FM cross sections can improve the accuracy of the DOAS fit since knowledge of the exact shape of the instrument's slit function is not required. For this purpose, FM measurements of temperature dependent absorption cross sections were performed for the GOME$2 \mathrm{~A}$ instrument during the on-ground, instrument calibration period (Guer, 2006). However, systematic errors in the FM ozone cross sections for GOME-2A (released in 2006) resulted in relative large DOAS fit residuals and larger wavelength shifts (Weber et al., 2011). Therefore, in the GDP 4.4, we used the GOME FM98 cross sections (Burrows et al., 1999) reconvolved with the GOME-2A slit function (Siddans et al., 2006), which provided consistent and stable results for GOME-2A (Loyola et al., 2011). Recently, improved FM ozone cross sections for GOME-2A were released, and the use of a quadratic parameterization of the FM cross sections was recommended for the retrieval of total ozone columns from GOME-2A (Chehade et al., 2013).

The Brion-Daumont-Malicet (BDM) ozone cross sections (Daumont et al., 1992; Malicet et al., 1995; Brion et al., 1998) have been recorded at high spectral resolution and have been recommended for use in ozone retrievals from spaceborne UV spectrometers (Orphal et al., 2002). The BDM data set has been used in the ozone profile retrieval from GOME (Liu et al., 2007) and OMI (Liu et al., 2013) measurements, the most recent solar backscatter UV (SBUV) total ozone and profile algorithm (Bhartia et al., 2013), and direct-fitting retrieval of total ozone data (Van Roozendael et al., 2012; Lerot et al., 2014). In this section we analyse the use of the improved GOME-2 FM and the high-resolution, $\mathrm{BDM}$ ozone absorption cross sections for the retrieval of total ozone columns from GOME-2A and GOME-2B.

One difficulty in retrieving total ozone in the Huggins bands is the temperature dependence of the ozone cross sections. In the GDP, the temperature dependence of the cross sections is taken into account by fitting a linear combination of two ozone cross sections at different temperatures (Richter and Burrows, 2002; Van Roozendael et al., 2002; Spurr et al., 2005). It is assumed that the temperature dependent cross sections can be linearly expanded as follows:

$\sigma_{\mathrm{O}_{3}}\left(T_{\mathrm{eff}}\right) \cong \sigma_{\mathrm{O}_{3}}\left(T_{1}\right)+\frac{\Delta \sigma_{3}}{T_{1}-T_{2}} \cdot\left(T_{\mathrm{eff}}-T_{1}\right)$,

where $\sigma_{\mathrm{O}_{3}}$ is ozone cross section, $T_{\text {eff }}$ is the $\mathrm{O}_{3}$ absorption effective temperature, and $\Delta \sigma_{\mathrm{O}_{3}}=\sigma_{\mathrm{O}_{3}}\left(T_{1}\right)-\sigma_{\mathrm{O}_{3}}\left(T_{2}\right)$. The dependence is linear if we assume the temperature derivative is constant throughout the limited range of stratospheric temperatures. We use $\sigma_{\mathrm{O}_{3}}\left(T_{1}\right)$ and $\Delta \sigma_{\mathrm{O}_{3}}$ as the reference cross sections in the DOAS fitting. The $\mathrm{O}_{3}$ slant column (SCD) and $T_{\text {eff }}$ can be derived through the relations 

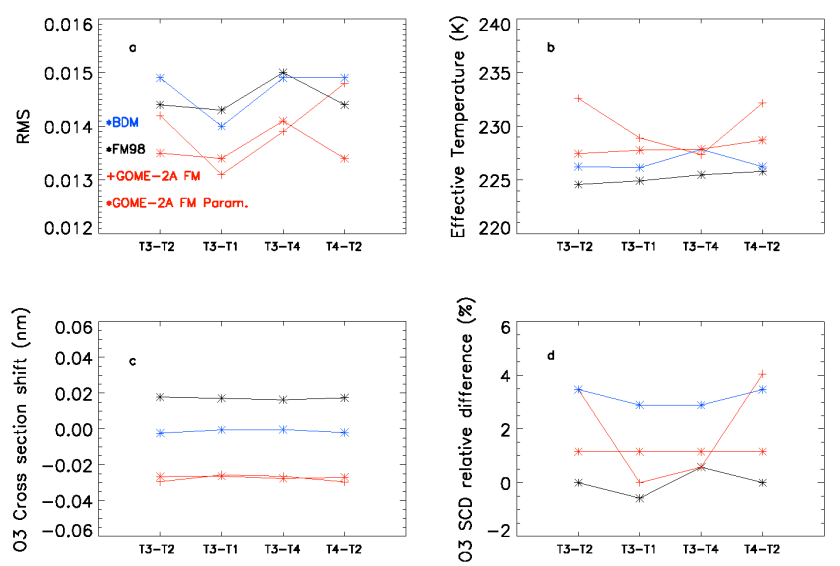

Figure 1. (a) RMS fit residuals, (b) effective temperatures, (c) $\mathrm{O}_{3}$ cross-section wavelength shifts, and (d) the change in $\mathrm{O}_{3}$ slant column relative to the column obtained using GOME FM98 cross sections at 241 and $221 \mathrm{~K}$ (GDP 4.4 settings), obtained after DOAS retrieval of the pixel 8500 of the GOME-2A orbit 20392, using different combinations of $\mathrm{O}_{3}$ absorption cross-section data sets. For the GOME FM98 data set, T1, T2, T3 and T4 represent 202, 221, 241 and $273 \mathrm{~K}$ respectively. For the GOME-2A FM data set, T1, T2, T3 and T4 represent 203, 223, 243 and $273 \mathrm{~K}$ respectively. For the BDM data set, T1, T2, T3 and T4 represent 218, 228, 243 and $273 \mathrm{~K}$ respectively.

$\tau_{\mathrm{O}_{3}} \cong \sigma_{\mathrm{O}_{3}}^{T_{1}} \cdot E_{1}+\Delta \sigma_{\mathrm{O}_{3}} \cdot E_{2}$,

$T_{\text {eff }}=T_{1}+\left(T_{1}-T_{2}\right) \cdot \frac{E_{1}}{E_{2}}$.

Here, $\tau_{\mathrm{O}_{3}}$ is the ozone slant optical density and $E_{1}$ the slant column density. As long as the assumption of linear dependency in temperatures is satisfied, the retrieval should in principle be independent of the temperatures selected for use in the DOAS fitting procedure.

The respective behaviour of the GOME FM98 cross sections reconvolved with the GOME-2A slit function (202, $221,241$, and $273 \mathrm{~K})$, the GOME-2A FM (203, 223, 243, and $273 \mathrm{~K}$, including a quadratic parameterization), and the BDM $(218,228,243$, and $273 \mathrm{~K})$ cross-section data sets are analysed. The DOAS fit results for GOME-2A have been analysed using the root mean squares (RMS) of fit residuals, the change in $\mathrm{O}_{3}$ slant column relative to the column obtained using GOME FM98 cross sections at 241 and $221 \mathrm{~K}$ (baseline GDP 4.4 settings), the retrieved effective temperature and the wavelength shift applied to the $\mathrm{O}_{3}$ cross sections (see Fig. 1). Results obtained with the GOME FM98 and BDM cross sections show stability in the sense that the values retrieved for each test parameter are independent of the selected temperatures of cross sections for processing. In contrast, results obtained with the GOME-2 FM ozone cross sections (unparameterized) show a much larger variability. Differences in
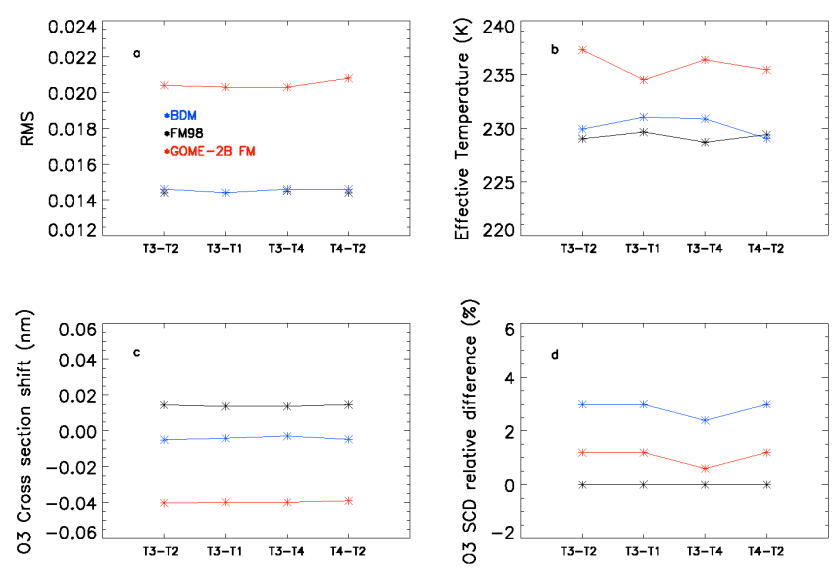

Figure 2. (a) RMS fit residuals, (b) effective temperatures, (c) $\mathrm{O}_{3}$ cross-section wavelength shifts, and (d) the change in $\mathrm{O}_{3}$ slant column relative to the column obtained using GOME FM98 cross sections at 241 and $221 \mathrm{~K}$ (GDP 4.4 settings), obtained after DOAS retrieval of the pixel 5144 of the GOME-2B orbit 5392, using different combinations of $\mathrm{O}_{3}$ absorption cross-section data sets. The meanings of T1, T2, T3 and T4 are the same as in Fig. 1.

$\mathrm{O}_{3}$ slant columns as large as $4 \%$ can be obtained depending on the combination of cross sections selected for retrieval, mostly as a result of the instability of the derived temperature (see Fig. 1b, d). If the GOME-2 FM quadratic parameterization is used instead of the individual FM cross sections, the scatter in the results is significantly decreased because quadratic parameterization can reduce the impact from inaccurate cross-section data at one temperature (Chehade et al., 2013). As shown in Fig. 1d, the total ozone column densities retrieved using parameterized GOME-2 FM cross sections are about $1 \%$ larger than the GDP 4.4 ozone columns obtained with the GOME FM98 cross sections. These results are consistent with similar analyses of the GOME-2A total ozone retrieval using the WFDOAS (Weighting Function DOAS) method (Chehade et al., 2013). Considering stability and the fit residuals, the parameterized GOME-2A FM cross sections at 243 and $223 \mathrm{~K}$ or the BDM cross sections at 243 and $218 \mathrm{~K}$ are good options for use in GOME-2A total ozone retrieval (see Fig. 1a).

Analyses of the total ozone columns retrieval from GOME-2B have also been performed using GOME FM98 reconvolved with the GOME-2B slit function (Siddans et al., 2012), GOME-2B FM cross sections (Guer, 2006), and the BDM cross sections. As shown in Fig. 2, using GOME-2B FM cross sections results in much larger fit residuals and $\mathrm{O}_{3}$ cross-section wavelength shift than when using GOME FM98 or BDM cross sections for GOME-2B ozone column retrieval. For this reason and to maintain the consistency between GOME-2A and GOME-2B total ozone retrievals, GOME-2A FM cross sections will not be used in the GDP before improved GOME-2B FM ozone cross sections are available. 

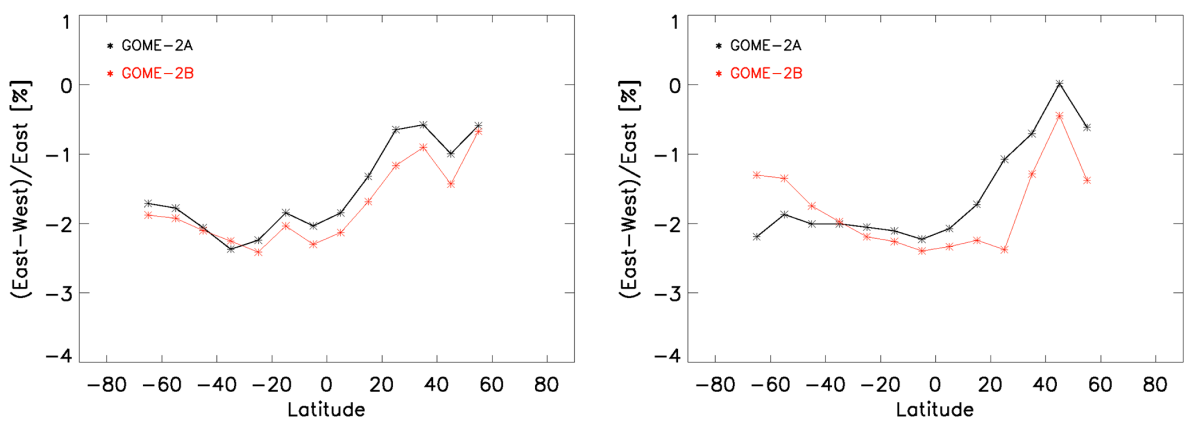

Figure 3. The scan angle dependency of ozone vertical column densities as function of latitude for GOME-2A (2008, black) and GOME-2B $\left(2013\right.$, red) for January (left) and June (right). East pixels represent scan angles smaller than $0^{\circ}$ and west pixels represent scan angles larger than $0^{\circ}$.

The use of the BDM data set has been recommended for ozone retrieval in the Huggins bands (Orphal, 2002). The BDM data set can significantly reduce fit residuals, and lead to smaller biases and standard deviation between GOME ozone profiles and ozonesonde measurements than when using the GOME FM cross sections (Liu et al., 2007). Also, the temperature dependence of the BDM data set appears to be reliable because the retrieved effective temperatures are generally in good agreement with effective temperatures derived from ECMWF (European Centre for MediumRange Weather Forecasts) model data (Van Roozendael et al., 2012). In addition, usage of the BDM data set produces high-quality fits and presents an accurate wavelength calibration (see Figs. 1 and 2). The GOME-2 ozone slant column densities retrieved using the BDM data set are about 2$3 \%$ larger than the ones retrieved using GOME FM98 cross sections. As described in the introduction, validation results (Balis et al., 2009; Loyola et al., 2011; Koukouli et al., 2012) show that in general GOME-2A ozone columns retrieved using GOME FM98 ozone cross sections (GDP 4.4 data) underestimate ground-based measurements and other satellite measurements. Therefore, BDM absorption ozone cross sections have been selected for use in the GOME- 2 total ozone retrieval with the GDP 4.7. To that end, the high-resolution BDM cross sections (at 243 and $218 \mathrm{~K}$ ) are preconvolved with the GOME-2A and GOME-2B preflight slit functions (Siddans et al., 2006, 2012) and a solar $I_{0}$ correction (Van Roozendael et al., 2006) has been applied.

\subsection{Correction for GOME-2 total ozone scan angle dependency}

The GOME-2A vertical ozone columns show a significant scan angle dependency (Antón et al., 2009; Loyola et al., 2011) with a bias of about $1.5-2 \%$ between ozone columns for the west and east ground pixels (west: positive scan angle; east: negative scan angle) within GOME-2 swath (West higher than east). As shown in Fig. 3, the pattern of scan angle dependency is very similar for GOME-2A and GOME2B for January and June (also for other months). This bias is not just a function of the scattering angle, but it also depends on the latitude and SZA, and it varies from month to month. This dependency might be partly attributed to possible remaining calibration issues in the GOME-2 level-1 product.

In the GDP 4.7, we use an empirical correction for the scan angle dependency to remove this bias in the ozone columns. Considering the similar pattern of scan angle dependency for GOME-2A and GOME-2B (as shown in Fig. 3) and the short time period of the GOME-2B data sets, we used 2 full years of GOME-2A data from the start of the mission (2007 and 2008) to calculate latitudinal monthly means of ozone columns for every forward scan angle position. The mean ozone column for the four centre scan angle positions (absolute scan angle $<10^{\circ}$ ) is selected as reference. In the end, a polynomial is fitted to the normalized measurements in order to remove outliers and to obtain a smoother correction function. Figure 4 presents the scan angle corrections for January and July. The effect of the empirical correction on GOME-2 total ozone columns is discussed in Sect. 3.2.

\section{Intercomparison between GOME-2A and GOME-2B total ozone columns}

\subsection{Effect of instrument degradation and slit function}

GOME-2A has suffered from instrumental degradation for a number of years (Dikty and Richter, 2011) and the reason for this degradation has not yet been fully identified. The degradation rates for GOME-2B are similar to those for GOME-2A (see http://www.eumetsat.int/website/home/ TechnicalBulletins/GOME2/index.html). Instrument degradation can affect DOAS retrievals in different ways like loss of signals and differential changes between the measured GOME-2 earthshine and irradiance spectra. Studies of instrument degradation and its impacts on level 2 data can be found in Lacan and Lang (2011) and Dikty and Richter (2011). As shown in Fig. 5, monthly averaged residuals for both GOME-2A and GOME-2B have been calculated for the clean equatorial Pacific region $\left(10^{\circ} \mathrm{S}-10^{\circ} \mathrm{N}\right.$, 


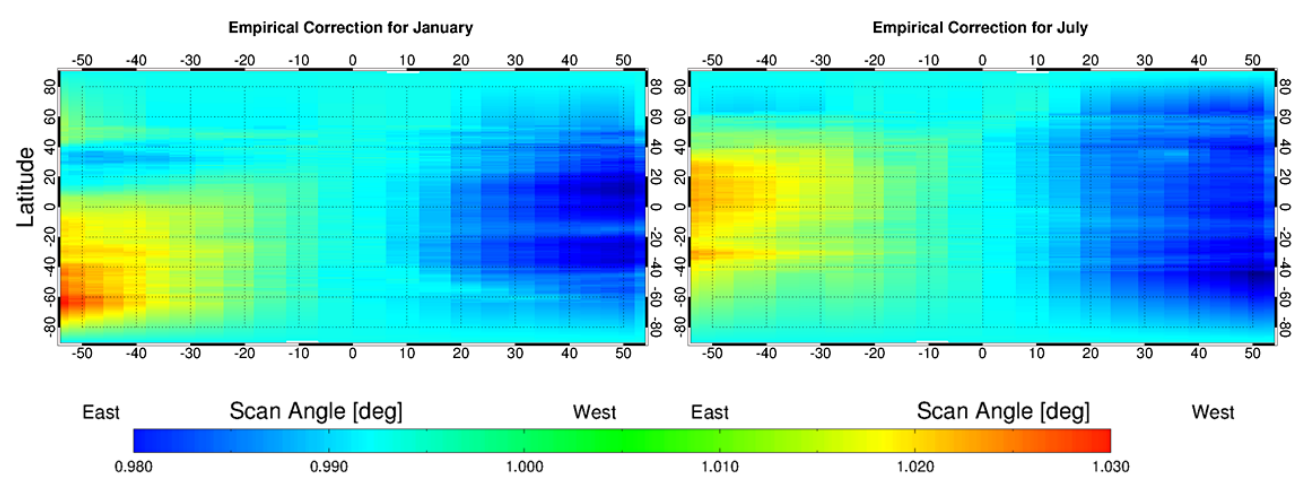

Figure 4. Empirical correction factors as a function of latitude and scan angle (East: scan angle $<0^{\circ}$; West: scan angle $>0^{\circ}$ ) for January and July. Correction ratios larger than one (red) are mostly found for the eastern part of the scan, while correction factors smaller than one (blue) correspond mostly to the western part of the scan.

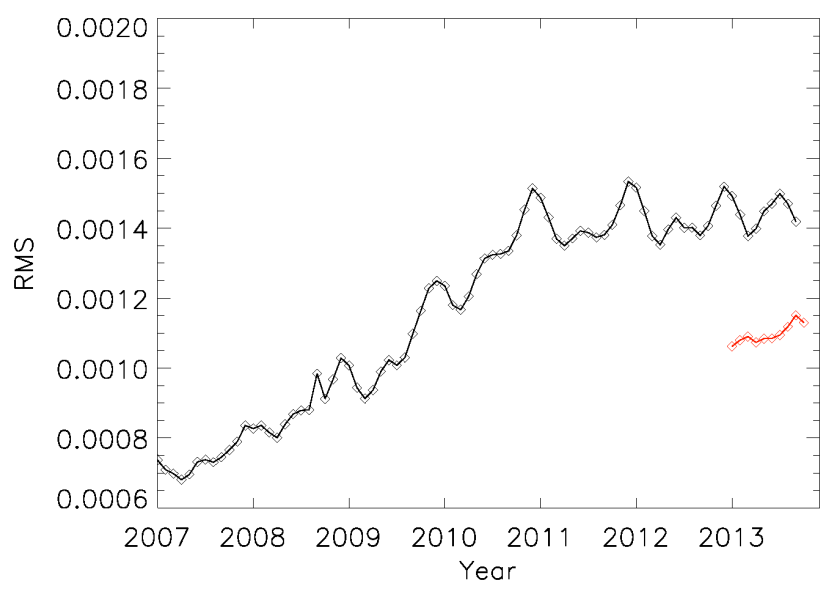

Figure 5. Long-term DOAS fitting residuals for the $325-335 \mathrm{~nm}$ ozone fitting window for GOME-2A (black line) and GOME2B (red line). The monthly averaged residual values have been calculated for the equatorial Pacific region $\left(10^{\circ} \mathrm{S}-10^{\circ} \mathrm{N}, 160^{\circ} \mathrm{E}-\right.$ $\left.160^{\circ} \mathrm{W}\right)$.

$\left.160^{\circ} \mathrm{E}-160^{\circ} \mathrm{W}\right)$. This figure illustrates the increase in the GOME-2A DOAS fit residuals as a function of time. The fit residuals increased by about $100 \%$ in the first 4 years of GOME-2A measurements. After June 2010, fit residuals did not increase anymore. The possible reason is that after an instrument throughput test (Lacan and Lang, 2011) carried out in September 2009 the rate of degradation has significantly slowed down (Dikty and Richter, 2011). Figure 5 also shows the increase in the GOME-2B ozone fit residuals as a function of time, and that the increase rate of fit residuals for GOME-2B is similar to those for GOME-2A at the beginning of operations in early 2007. However, although the fit residuals of GOME-2B are much smaller than those of GOME-2A in 2013, they are higher than those of GOME-2A in early 2007.

The width of the GOME-2 slit function has been narrowing with time (Lacan and Lang, 2011; Dicky and Richter,
2011). Recent investigations (De Smedt et al., 2012 and 2013) have shown that using a fitted asymmetric Gaussian slit function in GOME-2 retrievals of formaldehyde allows for a reduction of the fit residuals by about $18 \%$ compared to using the preflight slit function (Siddans et al., 2006). To study the impact of the slit function on $\mathrm{O}_{3}$ retrievals, effective slit functions have been derived from measured solar irradiance spectra by adjustment to the high-resolution solar reference of Chance and Kurucz (2010) and assuming an asymmetric Gaussian shape. For GOME-2B, fit residuals are reduced by about $12 \%$ when using an asymmetric Gaussian slit function, as opposed to the preflight slit function. Here, it should be noted that at the beginning of GOME-2A operations in 2007, no significant reduction of DOAS fit residuals were found when we did the same test. This indicates that unresolved issues may exist in the characterization of the GOME-2B slit function. However, the ozone fit residuals for GOME-2B are still about $25 \%$ larger than those of GOME-2A at launch time (2007) even when using the fitted slit function. The reasons are not clear yet and will be the subject of future research. In GDP 4.7, the preflight slit function is used to maintain the consistency between GOME-2A and GOME-2B total ozone retrievals.

\subsection{Intercomparisons of vertical column densities}

A statistical analysis of GOME-2A and GOME-2B data has been performed with respect to time, latitude, and other parameters. Here, it should be noted that all the data used for calculating the differences of total ozone column densities in this section are collocated data. The difference of collocated ozone vertical column densities (based on daily gridded data) from GOME-2B and GOME-2A is displayed in Fig. 6 for seven different days during the period from December 2012 to June 2013. A good agreement between GOME-2A and GOME-2B ozone columns is observed and the difference is within $1 \%$ for all latitudes. As shown in Fig. 7, the monthly average differences of ozone columns from GOME-2A and 


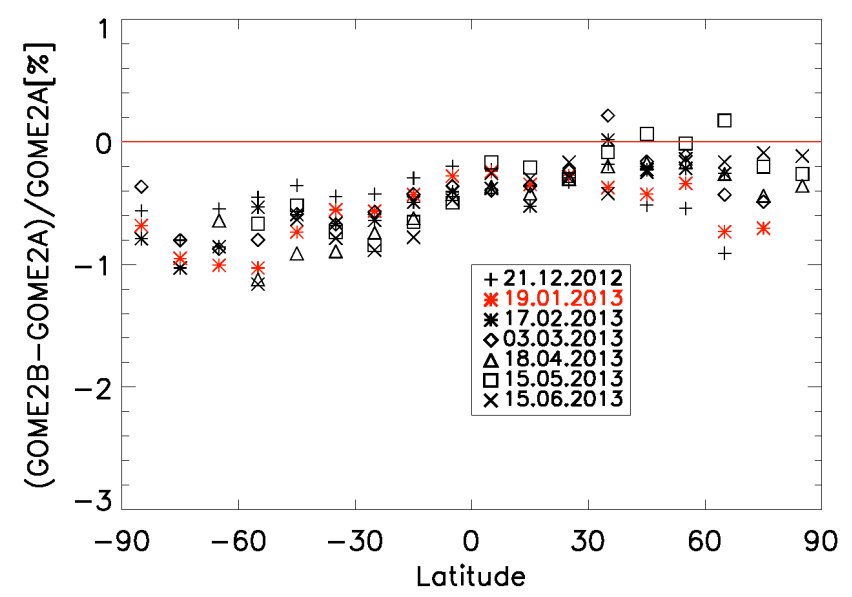

Figure 6. Latitudinal average differences (collocated data) of total ozone columns from GOME-2A and GOME-2B for 21 December 2012, 19 January, 17 February, 3 March, 18 April, 15 May and 15 June 2013.

GOME-2B (February and June 2013) are smaller than $1 \%$. The somewhat larger differences in high latitudes are related to low statistics in combination with strong natural ozone variations. Figure 8 presents the monthly mean time series of the ozone columns as a function of latitude. It reveals that the remaining months produce the similar comparison results as for February and June 2013. On average, GOME-2B produces $0.55 \pm 0.29 \%$ lower values than GOME-2A with larger differences (of up to $1.5 \%$ ) at high latitudes. Part of this difference is probably related to the different sampling of GOME-2A and GOME-2B over a single month (low statistics), and to partially corrected scan angle dependency.

In Fig. 9 the relative difference between the GOME-2A and GOME-2B total ozone columns as a function of total ozone columns (left panel) and SZA (right panel) is plotted. This figure shows that the differences do not depend on the total ozone column (GOME-2B underestimates total ozone by about $0.5 \%$ for all total column values). However, there is some SZA dependency in the bias between GOME-2A and GOME-2B total ozone. For low SZAs, the bias is small, but the difference between the GOME-2A and GOME-2B ozone columns increases with increasing SZA to about $0.5 \%$ at a SZA of $\sim 40^{\circ}$, with no further SZA dependency for larger SZAs.

In Fig. 10 the scan angle dependence is shown for the GOME-2B data set without and with the application of the empirical correction (see Sect. 2.2) for three different latitude regions. The east-west bias for the GOME-2B GDP 4.7 data set is reduced from -1.60 to $-0.42 \%$ (all latitudes), from -1.64 to $-0.12 \%$ (tropics) and from -0.97 to $0.16 \%$ (midlatitudes) by using the empirical correction.
4 GOME-2A and GOME-2B measurements of the 2013 Antarctic ozone hole

Figure 11 shows the total ozone column only from GOME$2 \mathrm{~A}$ and GOME-2B, and GOME-2A and $2 \mathrm{~B}$ for 18 October 2013, as retrieved with the GDP 4.7 algorithm described above. This figure illustrates the capacity of the combined use of GOME-2A and GOME-2B instruments to provide homogeneous total ozone data with full daily global coverage, and shows important features such as the Antarctic ozone hole and characteristics of the polar vortex. The 2013 Antarctic ozone hole began to form in the middle of August, reaching a maximum of $24.0 \times 10^{6} \mathrm{~km}^{2}$ which is larger than the ozone holes in 2012 and 2010, but smaller than that for 2011, according to the World Meteorological Organization (WMO) Antarctic Ozone Bulletin (http://www.wmo.int/pages/prog/arep/ WMOAntarcticOzoneBulletins2013.html) Figure 12 shows the Antarctic ozone hole for 29 September and 16 October measured from GOME-2A and GOME-2B. The minimum total ozone columns measured by the GOME- 2 on 29 September reached around 116 DU. It is interesting to note that $\mathrm{OMI} /$ Aura also measured a minimum ozone of $116 \mathrm{DU}$ on the same day. One can see from Fig. 12 that the edge of the ozone hole briefly touched the southern tip of the South American continent and affected inhabited places such as Ushuaia and Río Gallegos on 16 October 2013.

\section{Initial ground-based validation}

Ever since the first satellite-based total ozone observations became a reality, extensive validation activities have been carried out using well-known and dependable ground-based total ozone column (TOC) measurements. Total ozone data from the first Total Ozone Mapping Spectrometer (TOMS) have been validated using a suite of publicly available TOC measurements by Dobson spectrophotometers (Bojkov et al., 1988) whereas these comparisons have been continuously updated using a selection of both Brewer and Dobson measurements (Balis et al, 2007a; Antón et al., 2010). OMI/Aura TOC extracted from two different analysis algorithms were compared to ground-based measurements (Balis et al, 2007b). Needless to say, all new instruments, such as GOME-2/MetOp-A discussed above, are carefully compared against long-term, ground-based instruments to ensure the qualitative continuation of the global total ozone column record. The GOME-2A record has been extensively evaluated against a suite of Brewer and Dobson spectrophotometers in both Loyola et al. (2011) and Koukouli et al. (2012). Most recently, the same ground-based measurements were examined against the new version of the Solar Backscatter Ultraviolet (SBUV) instrument zonal mean total ozone columns record (Labow et al., 2013). 
Total $O_{3}$ Difference GOME-2B minus GOME-2A
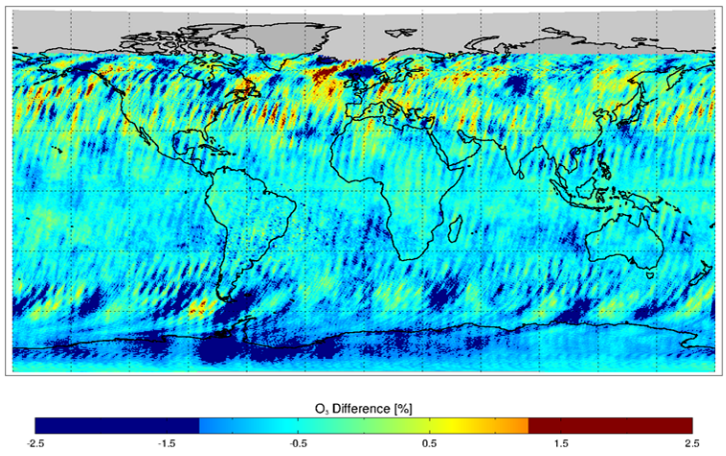

Total $O_{3}$ Difference GOME-2B minus GOME-2A

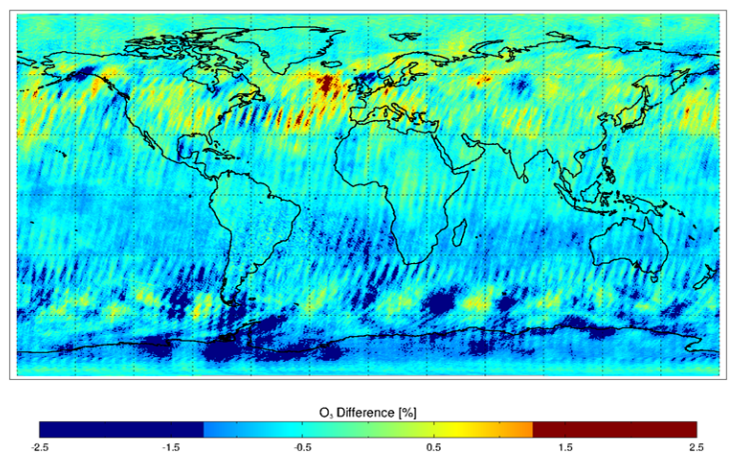

Figure 7. Monthly average differences between total ozone columns from GOME-2A and GOME-2B for February (left) and June 2013 (right).

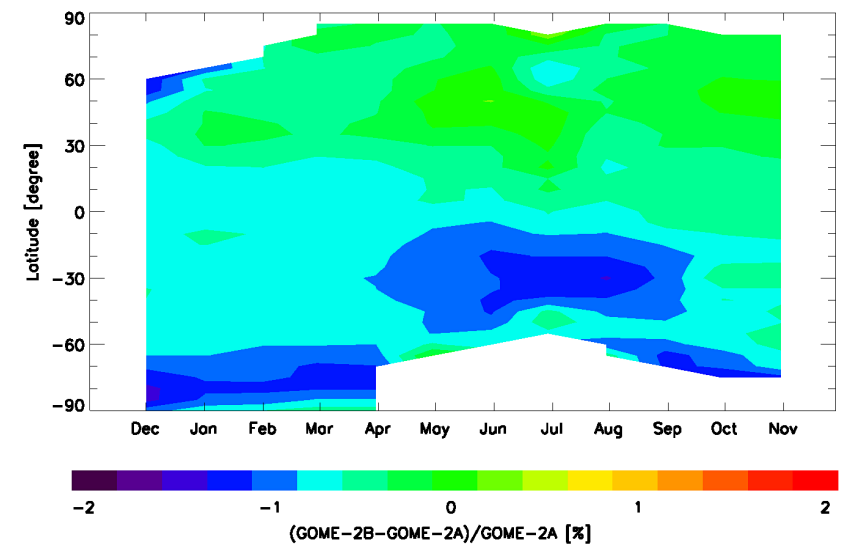

Figure 8. Time series of the zonally mean difference between GOME-2A and GOME-2B total ozone columns from December 2012 to November 2013.

The publicly available Brewer and Dobson spectrophotometer archived total ozone column measurements used as ground truth in this paper, as well as those mentioned above, reside at the World Ozone and Ultraviolet Radiation Data Centre (WOUDC) in Toronto, Canada (http://www. woudc.org), as part of the World Meteorological Organization (WMO) Global Atmosphere Watch (GAW) network. In terms of coverage, using carefully selected instruments from both the Dobson and Brewer network a wide geographical region can be covered on a global scale, with better coverage over the Northern Hemisphere than over the Southern Hemisphere and naturally no coverage over the sea. A total 38 Brewer stations and 21 Dobson stations considered for the comparisons in this paper are listed in Balis et al. (2013). As for the accuracy of the ground-based measurements, Dobson and Brewer data can agree within $1 \%$ when the major sources of discrepancy are properly accounted for (Van Roozendael et al., 1998). Staehelin et al. (2003) have also shown that small differences of around $\pm 0.6 \%$ might be observed between the two types of instruments, due to the use of different observational wavelengths and different temperature dependence for the ozone absorption coefficients. In particular, whereas the error of an individual well-calibrated Brewer instrument might be of about $1 \%$ (Kerr et al., 1988), Dobson instruments are known to suffer from a temperature dependence of the ozone absorption coefficients used in the algorithm which might account for a seasonal variation of $\pm 1.0 \%$ in the middle latitudes and $\pm 2.0 \%$ in the Arctic, and for systematic errors of up to $4 \%$ (Bernhard et al., 2005) depending on the instrument examined.

Daily relative differences between the ground-based total ozone measurements and GOME-2 are calculated using a $150 \mathrm{~km}$ search radius between the satellite centre of pixel and the geolocation of the ground-based station. In Fig. 13, the monthly mean relative differences for the Northern Hemisphere are presented for both the Brewer (left panel) and the Dobson (right panel) instruments. In order to show the stability and natural ozone variability during the GOME2A mission, the time series begins in January 2007. However, the relative differences during the months of December 2012-June 2013 are only calculated for the common pixels of GOME-2A and GOME-2B. Worthy of note in both panels, for both the GOME-2A and GOME-2B GDP 4.7 ozone record, is the positive offset between ground and satellite TOC, slightly larger for the Dobson case at $2 \pm 1 \%$ (right) than the Brewer case at $1 \pm 0.8 \%$ (left). Furthermore, a clear annual variability in the total ozone bias can be observed, which introduces a peak-to-peak difference of around 2-3\% in relative terms. For the 6 common months of observations of the two GOME2 instruments, the agreement is nearly identical.

Some statistics of the differences between GOME-2A and GOME-2B using the Dobson network as background TOC truth are presented in the histogram representation of the daily percentage differences shown in Fig. 14. In the left panel, the GOME-2A differences present an almost Gaussian curve peaking around $1.9 \pm 3.8 \%$ with a small increased 

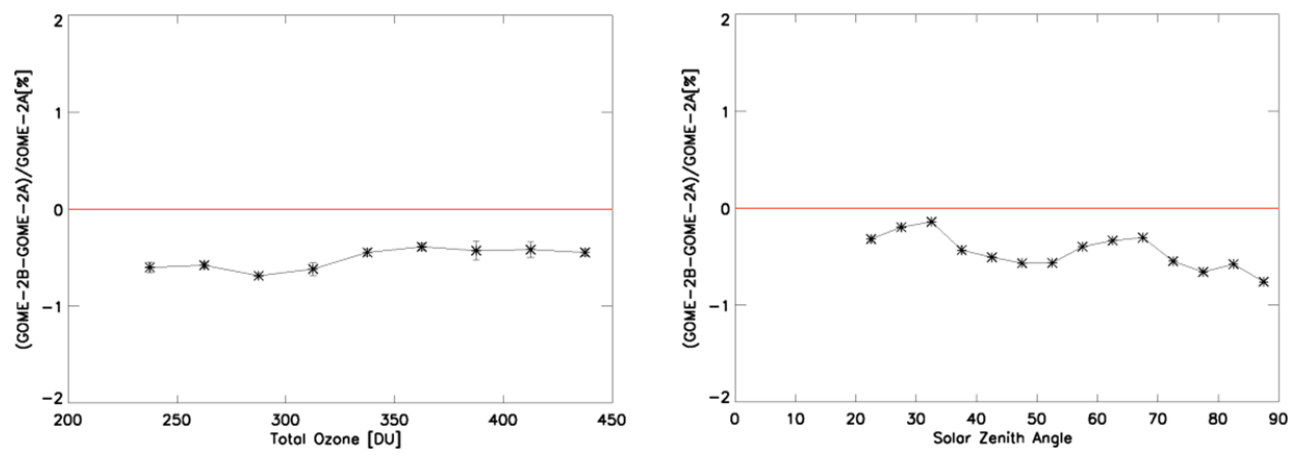

Figure 9. Relative difference between GOME-2A and GOME-2B total ozone columns as a function of total ozone column (left) and solar zenith angle (right). One year (from December 2012 to November 2013) of GOME-2A and GOME-2B data are used.
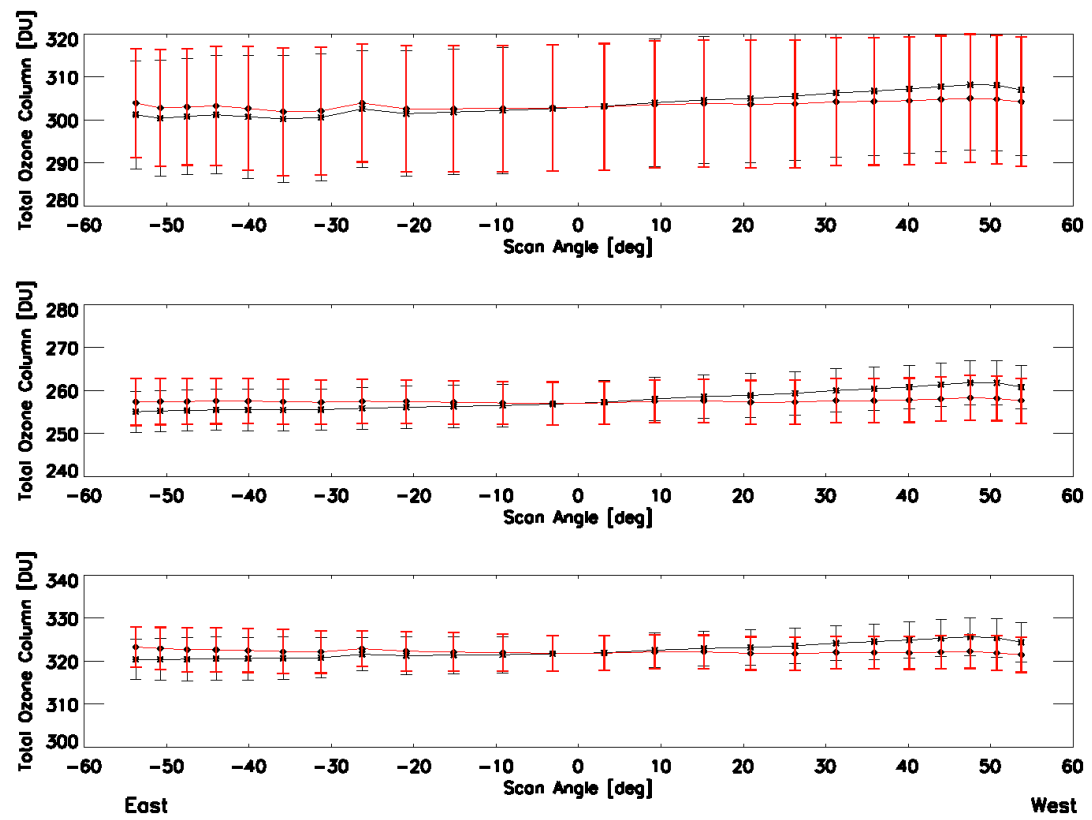

Figure 10. Dependency of GOME-2B total ozone column on instrument scan angle (forward scan only) without (black) and with (red) the empirical scan angle correction for all latitudes (top), tropics (middle) and midlatitudes (bottom).

bump in the negative values. In the right panel, the GOME2B differences are free from this bump and show a mean difference of $1.5 \pm 3.6 \%$ for the 1661 common points with the GOME-2A TOC data set. These results are quite consistent with the $0.55 \pm 0.29 \%$ mean global difference between GOME-2A and GOME-2B discussed in Sect. 3.2 above.

From the intercomparison exercise (Sect. 3) and the initial ground-based validation for the first 6 months of the GOME2B life time, it can be concluded that the TOCs retrieved with the GDP 4.7 algorithm for the two GOME-2 instruments are consistent. This is especially important for the tandem operation of the GOME-2A and GOME-2B instruments.

\section{Application of GOME-2A total ozone columns in MACC}

An important application of GOME-2 total ozone data is deployment in the MACC NRT system. The MACC NRT system (Stein et al., 2012) is run at T255 spectral truncation, corresponding to a reduced Gaussian grid (Hortal and Simmons, 1991) of about $80 \mathrm{~km}$ horizontal resolution. The vertical coordinate system is given by 60 hybrid sigma-pressure levels, with a model top at $0.1 \mathrm{hPa}$. The global fields serve as boundary conditions for an ensemble of European air quality models that provide higher-resolution air-quality forecasts. GOME-2A data are one of the ozone data sets assimilated in the current MACC NRT system to provide an ozone analysis from which to start the subsequent 5-day forecasts. The other ozone retrievals used in the MACC NRT system are 

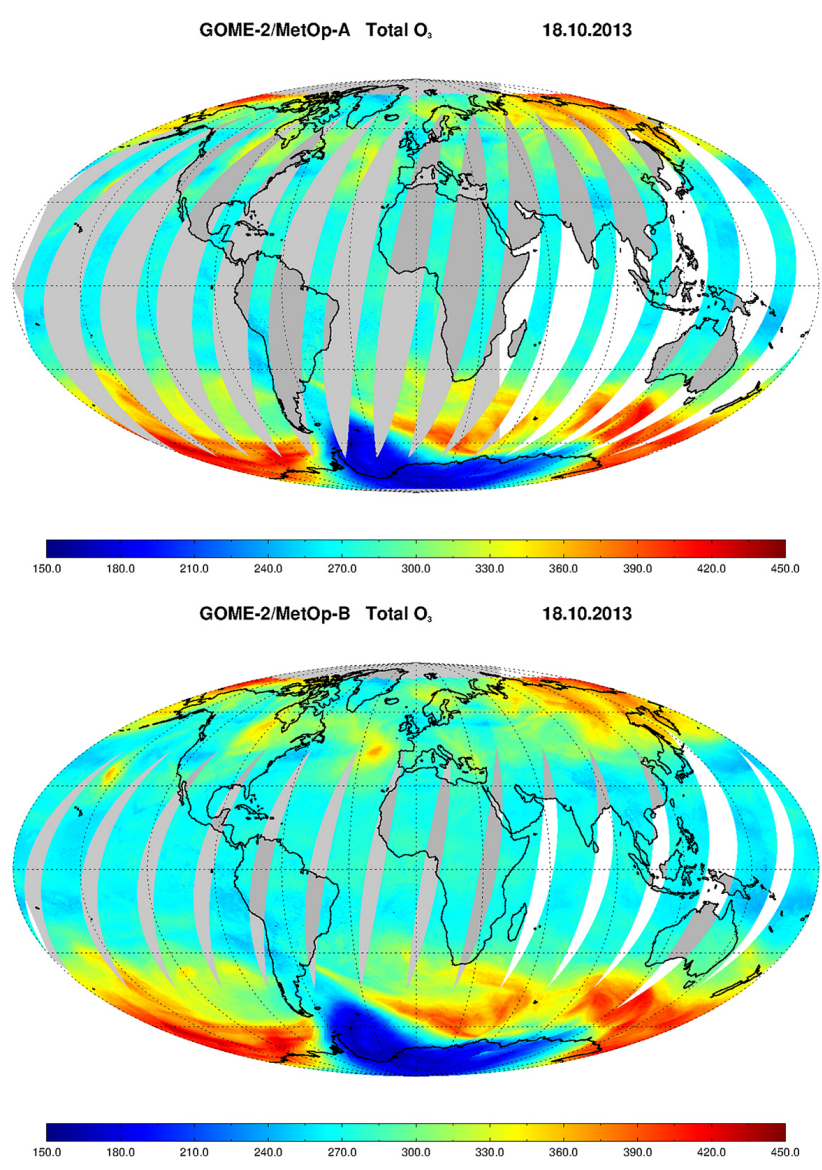

GOME-2/MetOp-A+B Total $\mathrm{O}_{3} \quad \mathbf{1 8 . 1 0 . 2 0 1 3}$

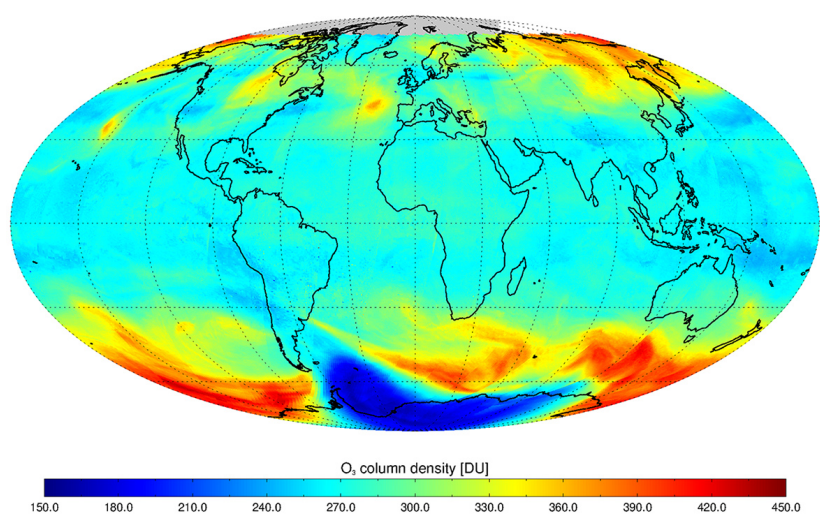

Figure 11. Total ozone column retrieved only from GOME2A (top) and GOME-2B (middle), and GOME-2A and 2B (bottom) on 18 October 2013.

MLS (Microwave Limb Sounder) ozone profiles (Waters et al., 2006; Livesey et al., 2011), OMI total columns (Bhartia et al., 2002; Levelt et al., 2006), and SBUV/2 ozone layers (Bhartia et al., 1996) from NOAA-16 and NOAA-19.

GOME-2 total ozone column data have been used in the MACC NRT system since 7 October 2013. Before this time the GOME-2 data were monitored passively and tested in offline assimilation experiments. "Monitoring" means that the data are included in the MACC system and first-guess and analysis departures of the data are calculated, but that the data are not used actively in the assimilation and have no impact on the ozone analysis. This procedure allows one to assess the quality of the data, the stability of the data provision, and to establish if there are biases between the data and the model, or between data from different instruments. If the quality of the monitored data is good and the data delivery is reliable, assimilation tests are performed in parallel to the operational MACC NRT analysis. If these assimilation tests are successful the data can be routinely assimilated in the MACC NRT analysis. Figure 15 shows this progression from monitoring to assimilation for GOME-2A TOC data. The top panel shows time series of first-guess and analysis departures for the period 1 February-30 September 2013 from the MACC NRT analysis which included the GOME2A TOC data passively at that time. The middle panel shows the same fields for an experiment in which the data were actively assimilated, and the bottom panel the number of data used in that experiment. The top plot shows a change to smaller departures in July 2013 when the GOME-2 data processor was upgraded to version GDP 4.7 and GOME-2A changed to half-width swath mode. The version change led to decreased GOME-2 departures, because GDP 4.7 data agree better with the MACC ozone field than GDP's previous version. At the same time the number of observations that was monitored was reduced. This reduction was a result of a prescreening that thins to $0.5 \times 0.5^{\circ}$ and is applied to the data in the MACC system to avoid oversampling and horizontally correlated observation errors. Because the data in half-width swath mode are closer together, more data were now removed by the prescreening. Apart from these changes the GOME-2 departures were stable. The middle panel shows that when GOME-2 ozone data are assimilated, departures and their standard deviation are reduced. The variational bias correction (Dee, 2004; Inness et al., 2013) applied to the data (black curve) absorbs the changes seen in the passive monitoring plot and first-guess and analysis departures were stable as the data were assimilated successfully. After the version change in July 2013 the magnitude of the bias correction was reduced (to about $-6 \mathrm{DU}$ in the global mean) because the data now agreed better with the analysis. The magnitude of the bias correction after the version change is similar to that applied to OMI TOC data (not shown). The long-term perspective of a succession of GOME-2 instruments made it desirable to include this instrument in the MACC NRT analysis.

\section{$7 \quad$ Summary and conclusions}

We have described the current operational total ozone retrieval algorithms for GOME-2A and GOME-2B, as implemented in the GDP version 4.7. Algorithm enhancements were introduced in GDP 4.7, including the usage of the BDM 

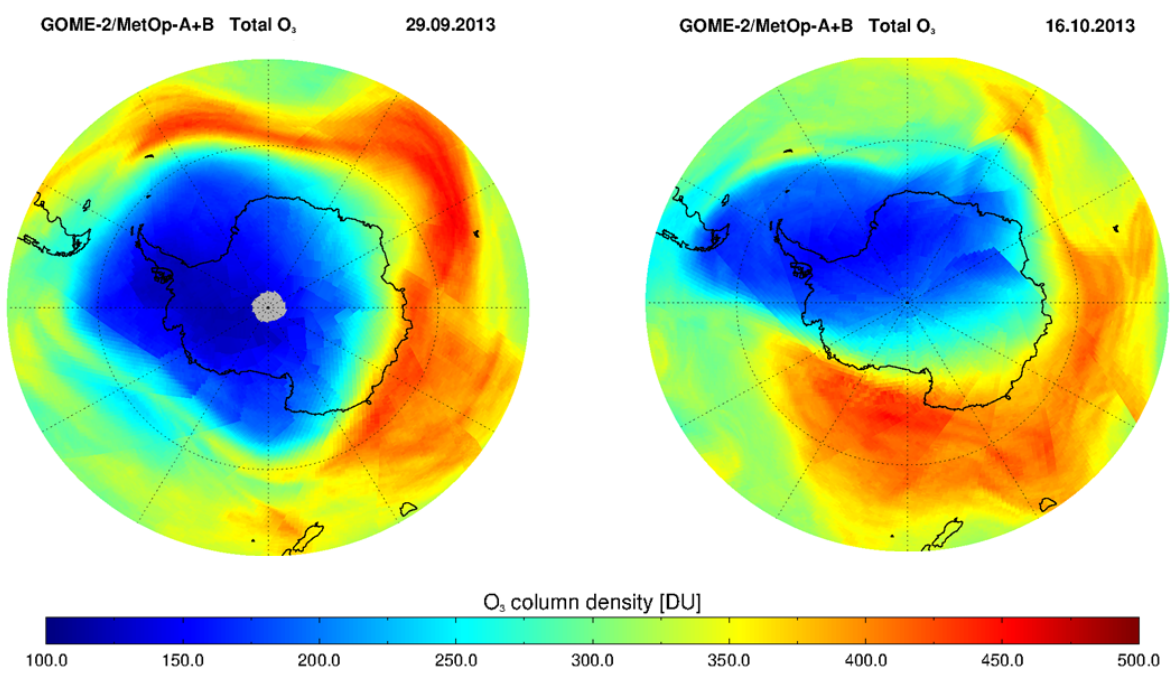

Figure 12. Total ozone maps for 29 September and 16 October 2013 based on data from GOME-2A and GOME-2B.
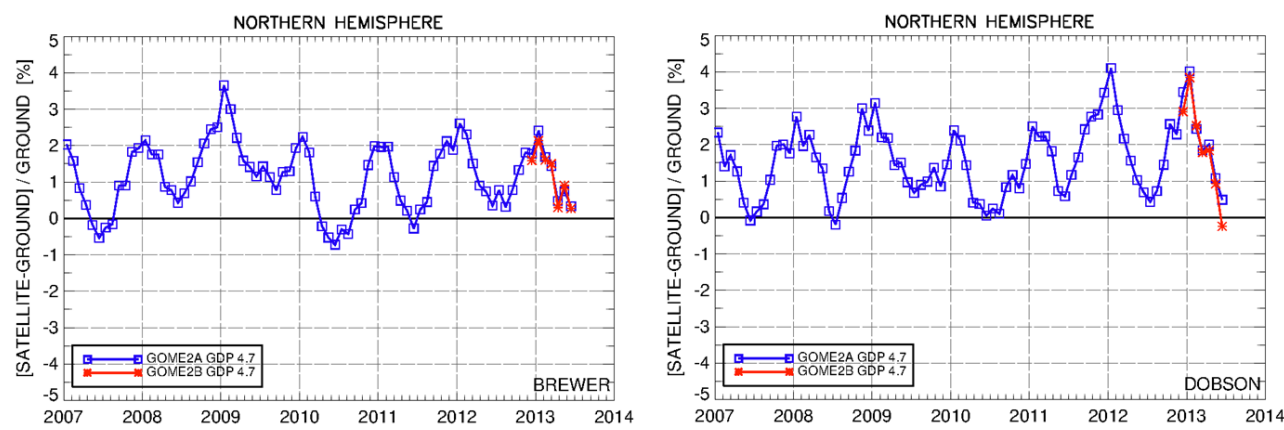

Figure 13. Time series of the monthly mean percentage differences between GOME-2A GDP 4.7 (blue line) and GOME-2B GDP 4.7 (red line) against the Northern Hemisphere Brewer stations (left panel) and the Northern Hemisphere Dobson stations (right panel).

ozone cross sections and an empirical correction to minimize the total ozone column dependencies on scan angle.

The consistency between GOME-2A and GOME-2B has been investigated using DOAS fit residuals and the retrieved total ozone columns. The GOME-2B ozone fit residuals are much smaller than those of GOME-2A in 2013, but about $40 \%$ higher than those of GOME-2A in early 2007 (beginning of MetOp-A operations). GOME-2B ozone fit residuals are reduced by about $12 \%$ when using an asymmetric Gaussian slit function rather than the preflight slit function. This indicates that remaining issues may exist in the characterization of the GOME-2B slit function. The known bias between the GOME-2A ozone columns for the east and west ground pixels (west being higher than east) was also seen in the GOME-2B ozone columns and has been largely eliminated with an empirical correction based on a statistical approach. On a global scale, GOME-2B is providing smaller total ozone columns by about $0.55 \pm 0.29 \%$ compared to GOME-2A. Part of this difference is probably related to the different sampling of GOME-2A and GOME-2B (low statistics at high latitudes), strong natural ozone variations, and not fully corrected scan angle dependency. The 2013 Antarctic ozone hole case study illustrated the capacity of the combined use of GOME-2A and GOME-2B instruments to provide homogeneous total ozone data with full daily global coverage.

The first global validation results for the first 6 months of GOME-2B total ozone measurements, using ground-based measurements, were presented. The average relative difference between GOME-2A TOC and Dobson observations is $1.8 \pm 3.9 \%$ for the 754 observations with the GOME-2A TOC data set and $1.5 \pm 3.7 \%$ for the GOME-2B data set. Even though only 6 months of data have been analysed so far, the TOCs provided by the GOME-2A and GOME-2B are consistent and may be used simultaneously without introducing systematic effects.

The GOME-2A total ozone data have been assimilated in the MACC NRT analysis since 7 October 2013 to provide an ozone analysis from which to start 5-day forecasts. The data are stable and have similar global mean biases to OMI TOC data that are also assimilated in the MACC NRT system. The good quality of the data and the prospect of a long-term 

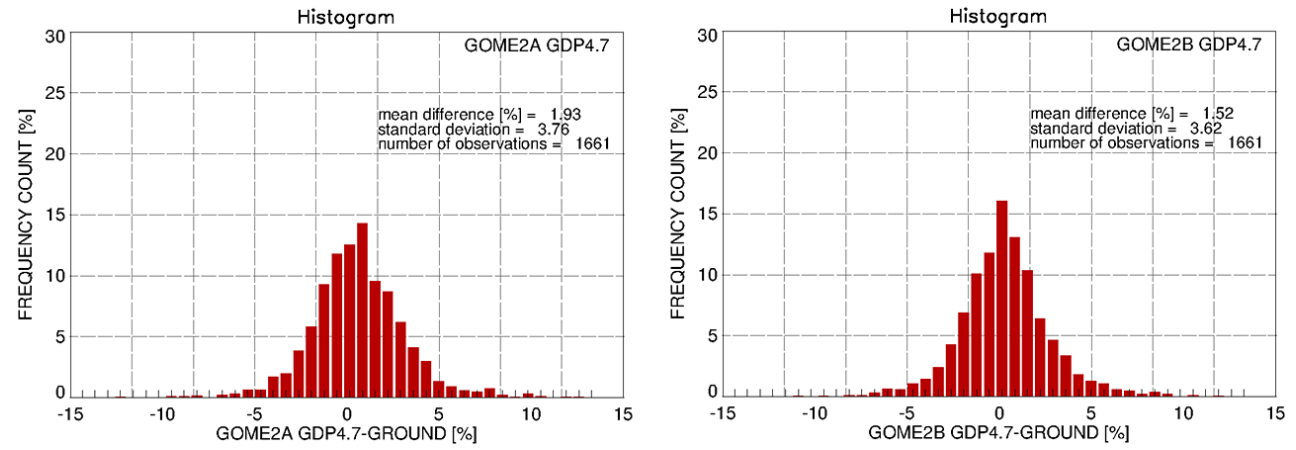

Figure 14. Histogram representation of the daily relative differences between GOME-2A GDP 4.7 (left panel) and GOME-2B GDP 4.7 (right panel) against the global Dobson station network in the period December 2012 to June 2013.
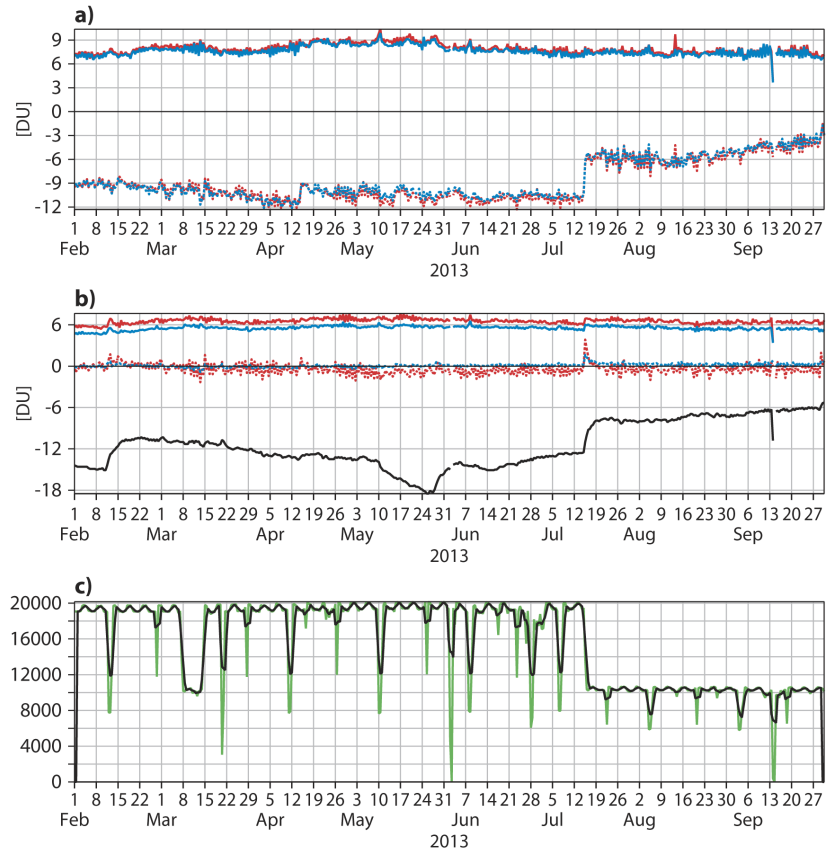

Figure 15. The top plots show the time series from 1 February to 30 September 2013 of first-guess (red) and analysis (blue) departures (dotted lines) and their standard deviations (solid lines) of GOME-2 total column ozone from the MACC NRT analysis which included the data passively; the middle plot shows the same for an experiment in which the GOME-2 TOC data were assimilated. The black line in the middle panel shows the bias correction applied to the data, and the bottom panel shows the number of observations used in this experiment.

GOME-2 TOC data record (at least until 2020) made it desirable to include this instrument in the MACC NRT analysis. Monitoring and assimilation tests of GOME-2B total ozone data in the MACC system will start soon.
The O3M-SAF operational GOME-2B total ozone products (starting from December 2012) are generated by the DLR. Total ozone generated with the GDP 4.7 is shown to be very accurate and the products are available in near-real time (i.e. $2 \mathrm{~h}$ after sensing), offline and reprocessed mode. They are freely available at http://atmos.eoc.dlr.de/gome2. More information about the ordering and download of products can be found in Valks et al. (2011). Results of the GOME-2 total ozone validation can be found at http://lap.physics.auth. gr/eumetsat/totalozone.

Acknowledgements. Development of the GOME-2 total ozone products and their validation has been funded by the O3M-SAF project with EUMETSAT and national contributions. The authors thank DFD colleagues S. Kiemle, K. H. Seitz, T. Padsuren and M. Schwinger, who are responsible for day-to-day operations of the O3M-SAF facility at the DLR. We thank EUMETSAT for the ground segment interfacing work with the O3M-SAF systems and for the provision of GOME-2 level 1 products. The authors would like to thank the ESA-MOST Dragon 3 cooperation project (ID: 10455). The Belgian national contribution was provided by the PRODEX A3C project. Ground-based measurements used in this work were taken from the World Ozone and Ultraviolet Data Centre (WOUDC; http://www.woudc.org). MACC-II was funded by the European Commission under the EU Seventh Research Framework Programme, grant number 283576.

The service charges for this open access publication have been covered by a Research Centre of the Helmholtz Association.

Edited by: J. Tamminen 


\section{References}

Antón, M., Loyola, D., López, M., Vilaplana, J. M., Bañón, M., Zimmer, W., and Serrano, A.: Comparison of GOME2/MetOp total ozone data with Brewer spectroradiometer data over the Iberian Peninsula, Ann. Geophys., 27, 1377-1386, doi:10.5194/angeo-27-1377-2009, 2009.

Antón, M., Koukouli, M. E., Kroon, M., McPeters, R. D., Labow, G. J., Balis, D., and Serrano, A.: Global validation of empirically corrected EP-Total Ozone Mapping Spectrometer (TOMS) total ozone columns using Brewer and Dobson ground-based measurements, J. Geophys. Res., 115, D19305, doi:10.1029/2010JD014178, 2010.

Balis, D., Lambert, J.-C., Van Roozendael, M., Loyola, D., Spurr, R., Livschitz, Y., Valks, P., Ruppert, T., Gerard, P., Granville, J., and Amiridis, V.: Ten years of GOME/ERS2 total ozone dataThe new GOME data processor(GDP) version 4:2, Ground-based validation and comparisons with TOMS V7/V8, J. Geophys. Res., 112, D07307, doi:10.1029/2005JD006376, 2007a.

Balis, D., Kroon, M., Koukouli, M. E., Brinksma, E. J., Labow, G., Veefkind, J. P., and McPeters, R. D.: Validation of Ozone Monitoring Instrument total ozone column measurements using Brewer and Dobson spectrophotometer ground-based observations, J. Geophys. Res., 112, D24S46, doi:10.1029/2007JD008796, 2007b.

Balis, D., Koukouli, M., Loyola, D., Valks, P., and Hao, N.: Validation report of GOME-2 total ozone products (OTO/O3, NTO/O3) processed with GDP 4.2, SAF/O3M/AUTH/GOME2VAL/RP/03, 2009.

Balis, D., Koukouli, M., Zyrichidou, E., Loyola, D., Valks, P., and Hao, N.: O3M SAF validation report for O3M-41 and O3M-42, SAF/O3M/AUTH/VRR/03, 2013.

Bernhard G., Evans, R. D., Labow, G. J., and Oltmans, S. J.: Bias in Dobson total ozone measurements at high latitudes due to approximations in calculations of ozone absorption coefficients and air mass, J. Geophys. Res., 110, D10305, doi:10.1029/2004JD005559, 2005.

Bhartia, P. K. and Wellemeyer, C.: TOMS-V8 Total $\mathrm{O}_{3}$ algorithm, in: OMI ozone product ATBD Volume II, NASA Goddard Space Flight Center, Greenbelt, MD, USA, 15-32, 2002.

Bhartia, P. K., McPeters, R. D., Mateer, C. L., Flynn, L. E., and Wellemeyer, C.: Algorithm for the estimation of vertical ozone profiles from the backscattered ultraviolet technique, J. Geophys. Res., 101, 18793-18806, doi:10.1029/96JD01165, 1996.

Bhartia, P. K., McPeters, R. D., Flynn, L. E., Taylor, S., Kramarova, N. A., Frith, S., Fisher, B., and DeLand, M.: Solar Backscatter UV (SBUV) total ozone and profile algorithm, Atmos. Meas. Tech., 6, 2533-2548, doi:10.5194/amt-6-2533-2013, 2013.

Bojkov, R. D., Mateer, C., and Hanson, A.: Comparison of ground-based and total ozone mapping spectrometer measurements used in assessing the performance of the global ozone observing system, J. Geophys. Res., 93, 9525-9533, doi:10.1029/JD093iD08p09525, 1988.

Brion, J., Chakir, A., Charbonnier, J., Daumont, D., Parisse, C., and Malicet, J.: Absorption spectra measurements for the ozone molecule in the 350-830 nm region, J. Atmos. Chem., 30, 291299, 1998

Burrows, J., Richter, A., Dehn, A., Deters, B., Himmelmann, S., Voigt, S., and Orphal, J.: Atmospheric remote sensing reference data from GOME: Part 2, Temperature-dependent absorption cross-sections of $\mathrm{O}_{3}$ in the 231-794 nm range, J. Quant. Spectrosc. Ra., 61, 509-517, 1999.

Chance, K. and Kurucz, R. L.: An improved high-resolution solar reference spectrum for earth's atmosphere measurements in the ultraviolet, visible, and near infrared, J. Quant. Spectrosc. Ra., 111, 1289-1295, 2010.

Chehade, W., Gür, B., Spietz, P., Gorshelev, V., Serdyuchenko, A., Burrows, J. P., and Weber, M.: Temperature dependent ozone absorption cross section spectra measured with the GOME-2 FM3 spectrometer and first application in satellite retrievals, Atmos. Meas. Tech., 6, 1623-1632, doi:10.5194/amt-6-1623-2013, 2013.

Daumont, D., Brion, J., Charbonnier, J., and Malicet, J.: Ozone UV spectroscopy I: Absorption cross-sections at room temperature, J. Atmos. Chem., 15, 145-155, 1992.

Dee, D. P.: Variational bias correction of radiance data in the ECMWF system, in: Proceedings of the ECMWF workshop on assimilation of high spectral resolution sounders in NWP, Reading, UK, 28 June-1 July 2004, 97-112, 2004.

De Smedt, I., Van Roozendael, M., Stavrakou, T., Müller, J.-F., Lerot, C., Theys, N., Valks, P., Hao, N., and van der A, R.: Improved retrieval of global tropospheric formaldehyde columns from GOME-2/MetOp-A addressing noise reduction and instrumental degradation issues, Atmos. Meas. Tech., 5, 2933-2949, doi:10.5194/amt-5-2933-2012, 2012.

De Smedt, I., Pinardi, G., Van Roozendael, M., Hao, N., and Valks, P.: O3MSAF ORR validation report, SAF/O3M/IASB/VR/HCHO/13, 2013.

Dikty, S. and Richter, A.: GOME-2 on MetOp-A Support for Analysis of GOME-2 In-Orbit Degradation and Impacts on Level 2 Data Products, Final Report, Version 1.2, 14 October 2011.

Guer, B.: Temperature Dependent Absorption Cross-Sections of $\mathrm{O}_{3}$ and $\mathrm{NO}_{2}$ in the $240-790 \mathrm{~nm}$ range determined by using the GOME-2 Satellite Spectrometers for use in Remote Sensing Applications, Ph.D. thesis, University of Bremen, 2006.

Hollingsworth, A., Engelen, R. J., Textor, C., Benedetti, A., Boucher, O. , Chevallier, F., Dethof, A., Elbern, H., Eskes, H., Flemming, J., Granier, C., Kaiser, J. W., Morcrette, J.-J., Rayner, P., Peuch, V.-H., Rouil, L., Schultz, M. G., Simmons, A. J., and the GEMS Consortium: The GEMS Consortium: toward a monitoring and forecasting system for atmospheric composition: the GEMS project, B. Am. Meteorol. Soc., 89, 1147-1164, doi:10.1175/2008BAMS2355.1, 2008.

Hortal, M. and Simmons, A. J.: Use of reduced Gaussian grids in spectral models, Mon. Weather Rev., 119, 1057-1074, 1991.

Inness, A., Baier, F., Benedetti, A., Bouarar, I., Chabrillat, S., Clark, H., Clerbaux, C., Coheur, P., Engelen, R. J., Errera, Q., Flemming, J., George, M., Granier, C., Hadji-Lazaro, J., Huijnen, V., Hurtmans, D., Jones, L., Kaiser, J. W., Kapsomenakis, J., Lefever, K., Leitão, J., Razinger, M., Richter, A., Schultz, M. G., Simmons, A. J., Suttie, M., Stein, O., Thépaut, J.-N., Thouret, V., Vrekoussis, M., Zerefos, C., and the MACC team: The MACC reanalysis: an $8 \mathrm{yr}$ data set of atmospheric composition, Atmos. Chem. Phys., 13, 4073-4109, doi:10.5194/acp-13-4073-2013, 2013.

Kerr, J. B., Asbridge I. A., and Evans W. F. J.: Intercomparison of total ozone measured by the Brewer and Dobson spectrophotometers at Toronto, J. Geophys. Res., 93, 11129-11140, 1988. 
Koukouli, M. E., Balis, D. S., Loyola, D., Valks, P., Zimmer, W., Hao, N., Lambert, J.-C., Van Roozendael, M., Lerot, C., and Spurr, R. J. D.: Geophysical validation and long-term consistency between GOME-2/MetOp-A total ozone column and measurements from the sensors GOME/ERS-2, SCIAMACHY/ENVISAT and OMI/Aura, Atmos. Meas. Tech., 5, 2169-2181, doi:10.5194/amt-5-2169-2012, 2012.

Labow, G. J., McPeters, R. D., Bhartia, P. K., and Kramarova, N.: A comparison of 40 years of SBUV measurements of column ozone with data from the Dobson/Brewer network, J. Geophys. Res.-Atmos., 118, 7370-7378, doi:10.1002/jgrd.50503, 2013.

Lacan, A. and Lang, R.: Investigation on GOME-2 throughput degradation, Final report, EUM/LEO/REP/09/0732 Issue 1.1, 16 July 2011.

Lerot, C., Van Roozendael, M., van Geffen, J., van Gent, J., Fayt, C., Spurr, R., Lichtenberg, G., and von Bargen, A.: Six years of total ozone column measurements from SCIAMACHY nadir observations, Atmos. Meas. Tech., 2, 87-98, doi:10.5194/amt-287-2009, 2009.

Lerot, C., Van Roozendael, M., Spurr, R., Loyola, D., ColdeweyEgbers, M., Kochenova, S., van Gent, J., Koukouli, M., Balis, D., Lambert, J.-C., Granville, J., and Zehner, C.: Homogenized total ozone data records from the European sensors GOME/ERS2, SCIAMACHY/Envisat and GOME-2/MetOp-A, J. Geophys. Res. Atmos., 119, 1639-1662, doi:10.1002/2013JD020831, 2014

Levelt, P. F., van den Oord, G. H. J., Dobber, M. R., Mälkki, A., Visser, H., de Vries, J., Stammes, P., Lundell, J. O. V., and Saari, H.: The ozone monitoring instrument, IEEE T. Geosci. Remote, 44, 1093-1101, 2006.

Liu, X., Chance, K., Sioris, C. E., and Kurosu, T. P.: Impact of using different ozone cross sections on ozone profile retrievals from Global Ozone Monitoring Experiment (GOME) ultraviolet measurements, Atmos. Chem. Phys., 7, 3571-3578, doi:10.5194/acp7-3571-2007, 2007.

Liu, C., Liu X., and Chance, K.: The impact of using different ozone cross sections on ozone profile retrievals from OMI UV measurements, J. Quant. Spectrosc. Ra., 130, 365-372, 2013.

Livesey, N. J., Read, W. G., Froidevaux, L., Lambert, A., Manney, G. L., Pumphrey, H. C., Santee, M. L., Schwartz, M. J.,Wang, S. H., Cofeld, R. E., Cuddy, D. T., Fuller, R. A., Jarnot, R. F., Jiang, J. H., Knosp, B. W., Stek, P. C., Wagner, P. A., and Wu, D. L.: Earth Observing System (EOS) Aura Microwave Limb Sounder (MLS) Version 3.3 and 3.4 Level 2 data quality and description document, available at: http://mls.jpl.nasa.gov/data/datadocs.php (last access: 5 March 2014), 2011.

Loyola, D., Thomas, W., Livschitz, Y., Ruppert, T., Albert, P., and Hollmann, R.: Cloud properties derived from GOME/ERS2 backscatter data for trace gas retrieval, IEEE Trans. Geosci. Remote Sens., 45, 2747-2758, doi:10.1109/TGRS.2007.901043, 2007.

Loyola, D. G., Koukouli, M. E., Valks, P., Balis, D. S., Hao, N., Van Roozendael, M., Spurr, R. J. D., Zimmer, W., Kiemle, S., Lerot, C., and Lambert, J.-C.: The GOME-2 total column ozone product: Retrieval algorithm and ground-based validation, J. Geophys. Res., 116, D07302, doi:10.1029/2010JD014675, 2011.

Malicet, J., Daumont, D., Charbonnier, J., Chakir, C., Parisse, A., and Brion, J.: Ozone UV Spectroscopy.II: Absorption cross cec- tions and temperature dependence, J. Atmos. Chem., 21, 163173, 1995.

Munro, R., Eisinger, M., Anderson, C., Callies, J., Corpaccioli, E., Lang, R., Lefebvre, A., Livschitz, Y., and Albinana, A. P. GOME-2 on MetOp, Proc. of The 2006 EUMETSAT Meteorological Satellite Conference, Helsinki, Finland, 2006.

Orphal, J.: A Critical Review of the Absorption Cross-Sections of $\mathrm{O}_{3}$ and $\mathrm{NO}_{2}$ in the $240-790 \mathrm{~nm}$ Region, Part I, Ozone, ESA Technical Note MO-TN-ESA-GO-0302, 2002.

Orphal, J.: A Critical Review of the Absorption Cross-Sections of $\mathrm{O}_{3}$ and $\mathrm{NO}_{2}$ in the ultraviolet and visible, J. Photochem. Photobiol., A157, 185-209, 2003.

Platt, U. and Stutz, J.: Differential Optical Absorption Spectroscopy: Principles and Applications (Physics of Earth and Space Environments), Springer-Verlag, Berlin, Heidelberg, ISBN 978-3540211938, 2008.

Richter, A. and Burrows, J.: Tropospheric $\mathrm{NO}_{2}$ from GOME measurements, Adv. Space Res., 29, 1673-1683, doi:10.1016/S02731177(02)00100-X, 2002.

Siddans, R., Latter, B. G., Kerridge, B. J., Smeets, J., Otter, G., and Slijkhuis, S.: Analysis of GOME-2 Slit function Measurements: Final Report Eumetsat Contract No. EUM/CO/04/1298/RM, 2006.

Siddans, R., Kerridge, B. J., Latter, B. G., Smeets, J., and Otter, G.: Analysis of GOME-2 Slit function Measurements Algorithm Theoretical Basis Document, Eumetsat Contract No. EUM/CO/04/1298/RM, 2012.

Spurr, R.: LIDORT and VLIDORT: linearized pseudo-spherical scalar and vector discrete ordinate radiative transfer models for use in remote sensing retrieval problems, in: Light Scattering Reviews, vol. 3, edited by: Kokhanovsky, A., Springer, Berlin, 229 275, doi:10.1007/978-3-540-48546-9_7, 2008.

Spurr, R., Loyola, D., Thomas, W., Balzer, W., Mikusch, E., Aberle, B., Slijkhuis, S., Ruppert, T., Van Roozendael, M., Lambert, J.C., and Soebijanta, T.: GOME level 1-to-2 data processor version 3.0: a major upgrade of the GOME_ERS-2 total ozone retrieval algorithm, Appl. Optics, 44, 7196-7209, 2005.

Staehelin, J., Kerr, J., Evans, R., and Vanicek, K.: Comparison of total ozone measurements of Dobson and Brewer spectrophotometers and recommended transfer functions, WMO TD N. 1147, No 149, 2003.

Stein, O., Flemming, J., Inness, A., Kaiser, J. W., and Schultz, M. G.: Global reactive gases forecasts and reanalysis in the MACC project, J. Integr. Environ. Sci., 9, 57-70, doi:10.1080/1943815X.2012.696545, 2012.

Valks, P., Pinardi, G., Richter, A., Lambert, J.-C., Hao, N., Loyola, D., Van Roozendael, M., and Emmadi, S.: Operational total and tropospheric $\mathrm{NO}_{2}$ column retrieval for GOME-2, Atmos. Meas. Tech., 4, 1491-1514, doi:10.5194/amt-4-1491-2011, 2011.

Van Roozendael, M., Peeters, P., Roscoe, H. K., De Backer, H., Jones, A., Vaughan, G., Goutail, F., Pommereau, J.-P., Kyrö, E., Wahlstrøm, C., Braathen, G., and Simon, P. C.: Validation of Ground-based UV-visible Measurements of Total Ozone by Comparison with Dobson and Brewer Spectrophotometers, J. Atmos. Chem., 29, 55-83, 1998. 
Van Roozendael, M., Soebijanta, V., Fayt, C., and Lambert, J.C.: Investigation of DOAS issues affecting the accuracy of the GDP version 3.0 total ozone product, in: ERS-2 GOME GDP 3.0 Implementation and Delta Validation, edited by: Lambert, J.-C., ERSE-DTEX-EOAD-TN-02-0006, ESA/ESRIN, 97-129, Eur. Space Agency, Frascati, Italy, 99-131, 2002.

Van Roozendael, M., Loyola, D., Spurr, R., Balis, D., Lambert, J.-C., Livschitz, Y., Valks, P., Ruppert, T., Kenter, P., Fayt, C., and Zehner, C.: Ten years of GOME/ERS-2 total ozone data-The new GOME data processor (GDP) version 4: 1. Algorithm description, J. Geophys. Res., 111, D14311, doi:10.1029/2005JD006375, 2006.

Van Roozendael, M., Spurr, R., Loyola, D., Lerot, C., Balis, D., Lambert, J.-C., Zimmer, W., van Gent, J., Van Geffen, J., Koukouli, M., Granville, J., Doicu, A., Fayt, C., and Zehner, C.: Sixteen years of GOME/ERS-2 total ozone data: The new direct-fitting GOME Data Processor (GDP) version 5-Algorithm description, J. Geophys. Res., 117, D03305, doi:10.1029/2011JD016471, 2012.
Waters, J. W., Froidevaux, L., Harwood, R. S., Jarnot, R. F., Pickett, H. M., Read, W. G., Siegel, P. H., Cofield, R. E., Filipiak, M. J., Flower, D. A., Holden, J. R., Lau, G. K. K., Livesey, N. J., Manney, G. L., Pumphrey, H. C., Santee, M. L., Wu, D. L., Cuddy, D. T., Lay, R. R., Loo, M. S., Perun, V. S., Schwartz, M. J., Stek, P. C., Thurstans, R. P., Boyles, M. A., Chandra, K. M., Chavez, M. C., Chen, G. S., Chudasama, B. V., Dodge, R., Fuller, R. A., Girard, M. A., Jiang, J. H., Jiang, Y. B., Knosp, B. W., LaBelle, R. C., Lam, J. C., Lee, K. A., Miller, D., Oswald, J. E., Patel, N. C., Pukala, D. M., Quintero, O., Scaff, D. M., Van Snyder, W., Tope, M. C., Wagner, P. A., and Walch, M. J.: The Earth Observing System Microwave Limb Sounder (EOS MLS) on the Aura satellite, IEEE T. Geosci. Remote, 44, 1075-1092, 2006.

Weber, M., Chehade, W., and Spietz, P.: Impact of ozone cross-section choice on WFDOAS total ozone retrieval applied to GOME, SCIAMACHY, and GOME2 (1995-present), Technical Note, available at http://www.iup.uni-bremen.de/ UVSAT_material/technotes/weber_acso_201311.pdf (last access: 5 March 2014), 2011. 